\title{
Economic and Political Factor of Songhay Empire the Emergence of Kebbi Kingdom Nigeria, c. 1500s
}

\author{
Seyni Mamoudou \\ Faculty of Law, Economics and Management FADEG, University of Tahoua, Tahoua, Niger \\ Email: msmaiga@hotmail.com
}

How to cite this paper: Mamoudou, S. (2021). Economic and Political Factor of Songhay Empire the Emergence of Kebbi Kingdom Nigeria, c. 1500s. Open Journal of Social Sciences, 9, 332-345. https://doi.org/10.4236/jss.2021.94026

Received: March 9, 2021

Accepted: April 23, 2021

Published: April 26, 2021

Copyright ( 2021 by author(s) and Scientific Research Publishing Inc. This work is licensed under the Creative Commons Attribution International License (CC BY 4.0).

http://creativecommons.org/licenses/by/4.0/

\begin{abstract}
The influence of the Almoravids movement in 1076 was one of the landmark developments that engendered the collapsed of Ghana Empire, from whence, Mali came into the limelight of political history in Western Sudan. From the second half of the $15^{\text {th }}$ century, Mali Empire became weakened and disintegrated and thus eventually led to the emergence and rise to glory of the Songhay Empire. The Songhay was the last of the great Empires of the Western Sudan and the language called the Emghedesi remained the lingua franca until the middle of the $19^{\text {th }}$ century. The expansion of the Songhay Empire since the second half of the $15^{\text {th }}$ century was mainly along the large arc of the Niger River, from Dendi (Gaya Dosso region-Niger) on Nigerian border. The Niger River became important commercial waterways with the development of Timbuktu and Jenne as the principal extrepots of Western Sudan trade. Besides, Kanta Mohammad (Salih), a local chief of a vassal area gave military supports to Songhay Empire and defended it against Air and Borno having been aided by Kano and Katsina. In addition, between 1516 and 1517, Kanta Mohammad and his army took part in a Songhay expedition against Agadez in which afterward quarreled with Dendi-fari over division of booty. With these developments, Kanta broke away with Songhay and established himself as an independent State of Kebbi. As a result of vicissitude of time, Leka became the early capital of Kebbi kingdom with the celebrated attack on Borno in 1561, the wall of Surame was already built. In the meantime, the heartlands of Kebbi which lie to the west of Sokoto fall between the lands bordering the Niger, inhabited by the Songhay-speaking people territories of Zamfara and Katsina. The paper adopted the qualitative analysis as well as synthesized research methodology has so far examined and interrogated of the factor of Songhay Empire in the emergence of Kebbi in c.1500s.
\end{abstract}




\section{Keywords}

Songhay Empire, Kebbi Kingdom, Emergence, Economic, And History

\section{Introduction}

The thrust of this study is a reconfiguration of the chequered history of the factor of Songhay Empire in the emergence of Kebbi in c. 1500s. Kebbi or Kasar Kabi was an offshoot, and fundamentally one of the provincial areas of Songhay Empire in the $16^{\text {th }}$ century. Songhay was the last of the great Empires of the Western Sudan. It is quintessential to construe that the Almoravids occupation was one of the external factors that effectuates the polity, which spawned the collapsed of Ghana Empire in c. 1076. It was from whence that Mali came into the limelight of political history in Western Sudan (Anene \& Brown, 1966). From the second half of the $15^{\text {th }}$ century, Mali Empire became weakened, and thus resulted in its decline and disintegration as well as the eventual emergence and rose to glory of Songhay Empire. It should be noted that in the second half of the $15^{\text {th }}$ century, many people had already settled mainly along the large arc of the Niger River because of its navigable waterways, from Dendi on Nigerian border. Albeit, the emergence and development of settlements of varied people along the Niger River became the fulcrum of administrative and commercial power of Songhay Empire that led to its apogee in the period under review. Ajayi and Crowder (1974) observe that it was through trade, the kingdom of Songhay became known to the Arabs by name of KawKaw, which may be referred to the combination of Gao-Kukiya complex.

It is imperative to know that Niger River to Songhay and its dependency areas contributed in no small measure to the development in the region. Abubakar, 2011; Yasin and Mukhtar, 1967 affirm that the base of power was on the bend of Niger River in the present day Niger, Mali and Burkina Faso. It could therefore be accentuated that from its capital at Gao (in the present day Mali republic), Songhay expanded in all directions until it stretched from the Atlantic ocean to what is now North-west Nigeria and western Niger Republics. Trimingham (1962) explication depicts that the Kebbi or Kebbawa (correctly Kabi) region lies on east of Dendi, between the Zarma and Hausa. Its people according to the tradition are a mixture of the two; therefore, 'the people of Kebbi' (Kabi) descended from a Katsina mother and a Songhay father. It is a fact to be known that the founder of Kebbi, Kanta Mohammad established a strong military might which sophistication was utilized in unprecedented supports for Songhay under the various Askias against internal and external attacks. Most critical and apposite to development are the military tactics, commercial interests and the Niger River advantages that spurred the territorial expansion Songhay Empire in the $14^{\text {th }}$ and $16^{\text {th }}$ centuries. In fact, it was also some of these factors or their wholesome combinations were responsible for its weakness and finally the collapse in the tail end 
of $16^{\text {th }}$ century.

By and large, with the Empire collapsed at the tail end of the $16^{\text {th }}$ century ( $c$. 1590-1591), the Songhay people founded another kingdom called Dendi, of which majority of the areas are in the modern-day Nigeria with some parts in the present day Niger republic. Among other settlements exemplified by Abubakar \& Mukhtar (2015) constituted the Gungawa and Shangawa ethnic groups who are presently found in Yauri Emirate and have to a very large extent traced their origins to Songhay people (Mukhtar, 2003). This, no doubt is unconnected with the south-south migration and warfare, which is important feature in the history of many people in West Africa, especially in the pre-colonial period. It is against the above prism, this paper is carved to explore and investigate the factor of Songhay Empire in the emergence of Kebbi in c. 1500s, vis-à-vis its consolidation and recrudescence. For better clarity, the paper is fragmented into distinct sections, apart from the introduction; secondly, it defines the territorial description of Songhay Empire and Kebbi Kingdom. Thirdly, it delineates on the factors that led to dispersion and territorial expansion of Songhay Empire. Fourthly, it explains Kebbi military sophistication and the defence of Songhay Empire; fifthly, it extols the factor of Songhay in the emergence, consolidation and recrudescence of Kebbi between $16^{\text {th }}$ and $17^{\text {th }}$ centuries and finally, the conclusion. It is amazing to understand that quite a number of areas in Nigeria; notably Kebbi, Zamfara and Katsina traced their origins to defunct Songhay Empire in the present day Niger Republic (Abubakar, 2011).

\subsection{Territorial Description of Songhay Empire and Kebbi Kingdom}

The Songhay Empire was the largest and last of the three major empires to emerge in West Africa. From its capital at Gao on the Niger River, Songhay expanded in all directions until it stretched from the Atlantic Ocean (modern Senegal and Gambia) to what is now Northwest Nigeria (Kebbi State is bordered by Sokoto State, Niger State, Zamfara State, Dosso Region in the Republic of Niger and the nation of Benin). Gao, Songhay's capital, the cities of Timbuktu and Djenne were the other major cultural and commercial centers of the empire. We can see on the Map in West Africa Songhay Empire and Kebbi Kingdom (1375-1591). (Figure 1)

From ab initio, Kawkaw is usually accepted as a name for the capital of the Songhay Kingdom who seat was first at Kukiya, on an island in the middle of Niger, about 120 miles upstream from the modern Tillebery, and later Gao, on the Niger bend (Fage, 1969). According to Laine (2001), the Songhai Empire was located in western Africa south of the Sahara desert and along the Niger River. At the peak, it stretched 1000 miles from the current modern day country of Niger to the Atlantic Ocean. Trimingham (1957) avers that Songhay is now spread in a large arc along the Niger from Dendi (on the Nigerian border) in the east to Lake Debo (south of Timbuktu) in the west. There are also Songhay communities in Mopti and Jenne. In the Hombori mountains, inside the Niger 


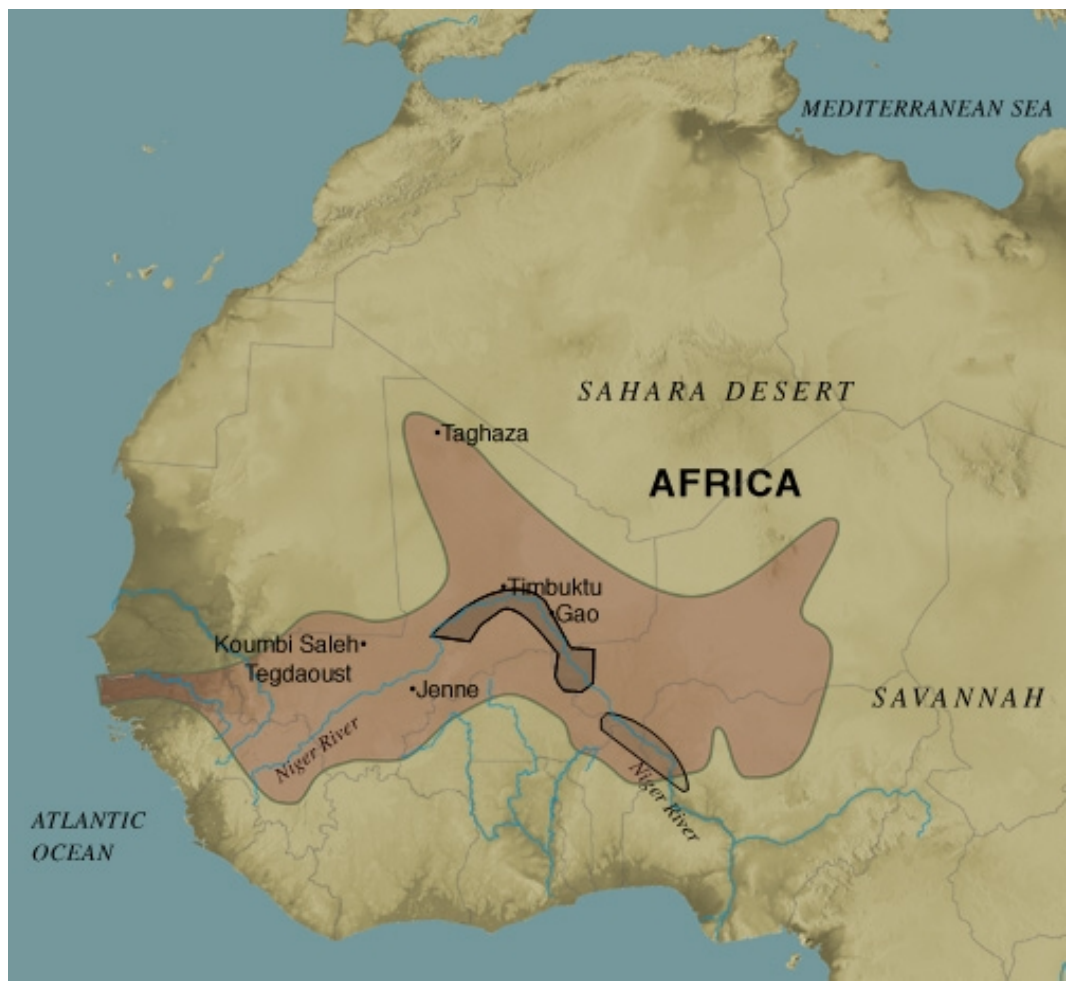

Source: Julianna Tesfu Posted on June 29, 2008.

Figure 1. West Africa Map Songhay Empire and Kebbi Kingdom (1375-1591).

bend are to be found the only land-locked, non-riverain Songhay peoples. Among other description, Levtzion (1974) maintains that the original and oldest peoples of Songhay were the Zarma (Djerma), Dendi and Kaado who belong, and form a classification of the Nilo-Saharan language family. These people and their settlements on the waterways informed why the vast majority of Songhay peoples are fishermen and agriculturalists who grow millet and sorghum in sandy fields or cultivate rice in the shallows of the Niger River (Figure $2 \&$ Figure 3).

Furthermore, Songhay geographical features is one of the harshest climates in the world, from October to May it does not rain and the dry period consists of two seasons. The cool season is dry, windy and dusty with daytime temperatures rising well above $27^{\circ} \mathrm{C}\left(80^{\circ} \mathrm{F}\right)$ and nighttime temperatures often plummeting below $10^{\circ} \mathrm{C}\left(50^{\circ} \mathrm{F}\right)$. By February, however, the daytime readings reach $38^{\circ} \mathrm{C}$ $\left(100^{\circ} \mathrm{F}\right)$ or more. By April and May, afternoon temperatures sometimes exceed $46^{\circ} \mathrm{C}\left(115^{\circ} \mathrm{F}\right)$. At night, the mercury drops only to $30^{\circ} \mathrm{C}\left(85^{\circ} \mathrm{F}\right)$ or so. However, the rains come in late May or early June and thus break the heat, and it lasts from June through September (Laine, 2001). In a nutshell, Songhay Empire is centered in the present-day Mali; it stretches from the Atlantic coast toward modern-day Niger and Nigeria. It is situated in the semi-arid Sahel, which consist of those rooky plains broken by rocky mesas in the south, and sandy dunes in the north. The key towns in Songhay include Gao and Timbuktu in Mali, and Ayoru, Tillaberi, Niamey and Tera in Niger (Olagunju, 2010). 


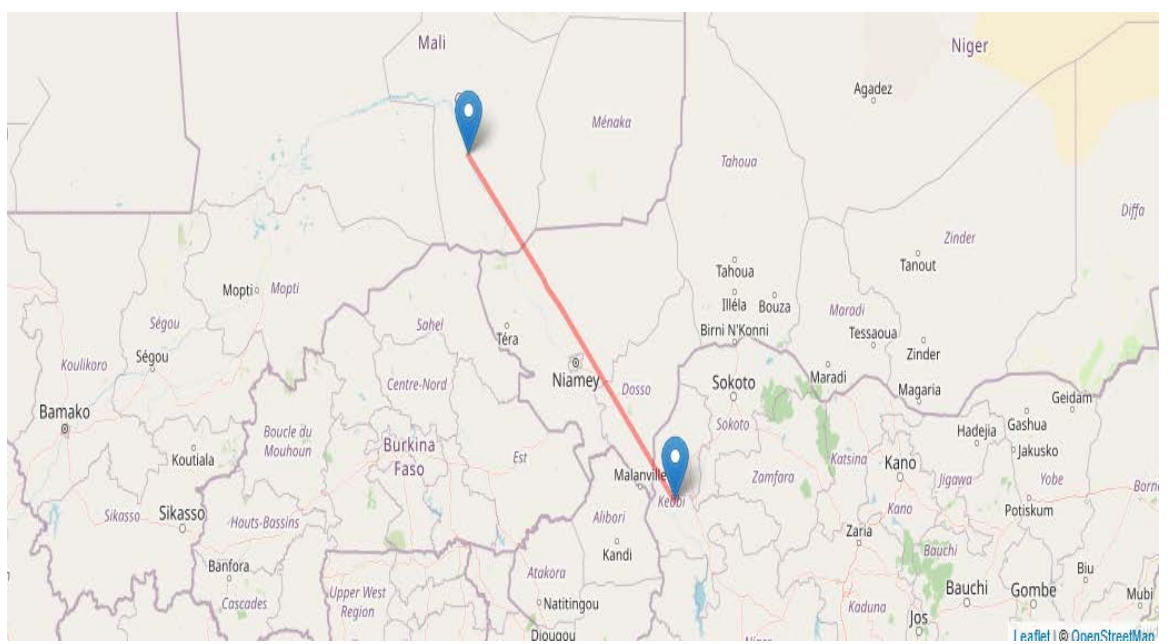

Source: https://www.distancefromto.net/distance-from-gao-to-kebbi. Distance between Songhay Empire capital Gao and Kebbi Kingdom is $673 \mathrm{~km}$ is equal 418 miles

Figure 2. Distance between Songhay Empire capital Gao and Kebbi Kingdom.

\begin{tabular}{|c|c|c|c|}
\hline \multicolumn{2}{|l|}{ Gao } & \multicolumn{2}{|l|}{ Kebbi } \\
\hline \multicolumn{2}{|l|}{ Gao is located in Mali. } & \multicolumn{2}{|c|}{ Kebbi is located in Nigeria. } \\
\hline GPS Coordinates (DMS) & $\begin{array}{l}16^{\circ} 15^{\circ} 50.3280^{\prime \prime} \mathrm{N} \\
0^{\circ} 1^{\prime} 40.7640^{\prime \prime} \mathrm{W}\end{array}$ & GPS Coordinates & $\begin{array}{l}11^{\circ} 40^{\circ} 41.2320^{\prime \prime} \mathrm{N} \\
4^{\circ} 4^{\prime} 10.3800^{\prime \prime} \mathrm{E}\end{array}$ \\
\hline Latitude & 16.26398 & Latitude & 11.67812 \\
\hline Longitude & -0.02799 & Longitude & 4.06955 \\
\hline Altitude & $250 \mathrm{~m}$ & Altitude & $258 \mathrm{~m}$ \\
\hline Country & Mali & Country & Nigeria \\
\hline
\end{tabular}

Source: https://www.distancefromto.net/distance-from-gao-to-kebbi.

Figure 3. The specific location, longitude and latitude information.

In the case of the Kebbawa jurisdiction, Trimingham (1962) explication depicts that the Kebbi (correctly Kabi) region lies east of Dendi, between the Zarma and Hausa, its people according to tradition are mixture of the two. Therefore, it could be emphasized that 'the people of Kebbi (Kabi) descended from a Katsina mother and a Songhay father. Prior the emergence of Sokoto Caliphate in the $19^{\text {th }}$ century, most of the landmass were dominated by the powerful kingdom of Kebbi as affirms by Anene \& Brown (1966) and was carved out of the Songhay Empire by Kanta Muhammad, which includes two confederations of Yauri and Zuru (Olagunju, 2010). Besides, the heartlands of Kebbi, which lie to the west of Sokoto, fall between the lands bordering the Niger, inhabited by the Songhay-speaking Dendawa (Dendi) and the Hausa-speaking territories of Zamfara and Katsina. Muhammad Bello represents the Kebbawa as a mixed Hausa-Songhay people (Hogben \& Kirk-Greene, 1966) and to this day the taubashi or tribal "cousinship" between them and the Katsinawa is maintained (Ajayi \& Crowder, 1974).

\subsection{The Dispersion and Territorial Expansion of Songhay Empire's Dependency Areas}

Myriads of external and internal factors came into play in the dispersion and 
territorial expansion of Songhay and its dependencies or vassal areas along the Niger River. The factor could be deciphered in Niger River; commerce interest; its geographic and strategic position; polity and military might of Songhay Empire in the period under review. The synergy of the factor played decisive and ultimate role in the administrative formation, dispersion and territorial expansion of Songhay Empire between the $15^{\text {th }}$ and $16^{\text {th }}$ centuries.

Foremost of the factor included the navigability of Niger River that attracted numerous fishermen prominent among which are the Sorko or Sorkawa and farmers of cereal crops. Their emergence on the river enhanced Songhay to wield considerable sways and influence that spurred the birth of numerous settlements and people; comprising the Sorko, Zerma, Gungawa and Shangawa of Yauri among others. More significantly, Levtzion in Ajayi and Crowder (1974) underscores that the Niger River played fundamental functions not only in the dispersion of the Songhay, but also in the expansion of their imperial dominions when the Empire became dominant in the Sudan. Their dependence on a water course for expansion is best illustrated by the plan of Sonni 'Ali to dig a canal from Ra's al-Ma to Walata in order to conquer this town of the Sahil (Sahel), (Trimingham, 1962). This development not only aided military conquest, but also influenced mobility which is significantly critical to the settlement of different people along the bank of Niger River.

It is also pertinent to express that the dominant elements among the Songhay were the Sorko fishermen of the Niger of which their existence in the area accelerated settlement of different ethnic groups. The complementary element which together with the Sorko formed are constituent of heterogeneous people who were the Gow hunters and the Do farmers. The Sorko navigated up the river from Dendi and reached the region of Bentia, north of Tillabery, where they found hippopotami in abundance. Critical to the territorial expansion of Songhay Empire are the mobile and warlike nature of the people, the Sorko became not only 'masters of the water' but also rulers of the farmers, owners of the earth, who lived in the region of Bentia. There they were joined by the hunters and a town by the name of Kukiya developed as the capital of the Songhay nation (Levtzion, 1974).

It is essential to note that Kawkaw was the greatest kingdom of the Sudan, with a large tributary States (Fage, 1969) which influenced the Sorko fishermen to carry out their activities, a factor that stimulated number of settlements in the middle of the Niger river (Trimingham, 1962). Abubakar \& Mukhtar (2015) identified that one of the territories that witnessed the diffusion of the Songhay people long before its final collapse at the tail end of the $16^{\text {th }}$ century was Yauri Kingdom. They accentuates that the dispersal in the Yauri area at that time was facilitated by the passage of the Niger River in the Kingdom.

More so, Fage (1969) pointed out the pertinence of Mali in the expansion of Songhay Empire as an establishment or offshoot of the former. It could be stressed further that the reassertion of Songhay independence on the Niger bend 
and middle Niger made Mali to utterly depend on Songhay boat for its vital line of communication along and beyond Jenne to all important trans-Sahara trade routes and to Hausaland. It is argued that by about 1300, its rulers (Mali) had made their power effective as far as Gao, and thus had come to dominate the Songhay boatmen and fishermen (Sorko) who control activities on the Niger from just upstream of Timbuktu to as far downstream as Kebbi, on the borders of modern Nigeria (Fage, 1969).

Again, the dispersion and territorial expansion was instigated by the inherent trade and commercial relation which vantage in Songhay Empire simultaneously injected the rise and growth of other towns. For instance, Levtzion in Ajayi and Crowder (1974), asserted that at the time, the trade between Timbuktu and Jenne flourished in an independent country lying between the declining Mali and the rising of Songhay. It should be noted that the development of boatmen, fishermen and agricultural cultivators boosted the economy of Songhay to an unimaginable degree leading to emergence of communities along the arc of Niger River. Through this development, Songhay Empire became the commercial artery which influenced proliferated the exchanges of ware as entreport for the northern and the people of southern coastal areas. In the long-run, this factor coupled with growth of outpost markets enhanced the emergence of towns such as Kebbi (Kabi) in c. 1515 and Argungu in Songhai region (Olagunju, 2010). Also, the influence of the geographic and strategic position of Songhay aided the economic viability that converted the region to an important emporium of trade and commerce of the erstwhile trans-Sahara trade. The foregoing fact therefore informed the development of outpost markets in the Empire's accretion in exchange of wares, agricultural products technological ideas and ideologies became noticeable and enormous.

Again, a salient factor to the dispersion and expansion of Songhay Empire was its formidable military strength that emanated from the administrative arrangement and formation of governance. According to Webster, Boahen, \& Idowu (1967) militarism for territorial defence and expansion was the ubiquitous features of western Sudanese States survival. Evident was the compartmentalization of Songhay Empire on the line of provincial platform controlled and coordinated by a commander of army-General. It was based on this that Kanta Mohammad of Kebbi was appointed a military-General entrusted in his command thousands of army in the $16^{\text {th }}$ century functionally to assuage the defence and survival of its overlord. It is interesting note that Kanta was a veteran army General in the Songhay, which military might had helped to strengthen the administrative efficacy as well as territorial defence against some external onslaughts. In some record, it is believed that the spread of political influence and military strength of Songhay occasioned the emergence Kebbi (Kabbawa) as well as Zamfara, Katsina and Yauri among others. Even the offensive tactics of Songhay in the conquest of vast territories at its zenith was tremendously advocated by the defensive and invincibility of Kanta Mohammad of Kebbi military overlord against Borno, Agades, Morocco etc. It was in line with Kanta military disposition and 
effervescent greatness that Songhay fame became noticeable in Western Sudan as well the establishment of numerous areas.

\section{Kebbi Army Sophistication and the Defence of Songhay Empire}

It is an incontestable fact that Kebbi or the Kabbawa as normally refers to in Hausa coinage are one of the outgrowths of the Songhay Empire. It is not an ancient aberrant to analyse and confer the emergence of the Kebbawa from a long drawn of an inclined overbearing military machination against all odds. This was because Empire building as exemplified in the preceding segment in antiquity is inundated with pertinence of military sophistication and tactics for both administrative and economic survival and sustainability. On this note, it is amazing to construe that Kanta gained independent and recognition through military sovereignty from the continuous assistance in the defence of Songhay territory and expansion of its numerous dependency areas against external aggression. Therefore, it is germane from available records to pontificate, and as corroborated by Ajayi and Crowder (1974) that nothing definite is known of the history of Kebbi (kabi) before the rise of the first Kanta, Kuta (Kotal-meaning 'no challengers'), who rose from being an insignificant local chief to become a vassal and military support of the Songhay Empire. However, Kanta Mohammad was suggested to might have been probably a client of the Dendi-fari, governor of the extreme south-easterly province of Songhay, with responsibility for the left (ausa) bank.

Although abound among other works included Anene and Brown (1966); Webster, Boahen, \& Idowu (1967) that Songhay was compartmentalized into different principalities or provinces coordinated and governed by a war commander who were assisted by a Muslim clergy. This system was probably what prompted Kanta militarily to carve an area of influence from the revolt that was later pregnated with many intrigues in Songhay Empire. In between I5I6 and 15I7, he and his army took part in a Songhay expedition against Agades, but afterwards quarreled with the Dendi-fari over the division of booty and, breaking his ties with Songhay, established himself as an independent State and ruler. From this time on, he remained independent and was able to build up a powerful State on the eastern edges of the Songhay Empire. During its two hundred years life-span is reported to have held sway at one time or another over Katsina, Kano, Gobir, Air (Azben or Azhbenawa) and a part of Songhay (Ajayi \& Crowder, 1974). In fact, the unbridled military assistance rendered by Kanta Mohmmad to Songhay further strengthened other factors in the evolution and origin of a powerful kingdom (Kebbi) which fame was renown throughout Hausaland, Air, Morocco and Agades among others.

Through its unimaginable and unequivocal strength, the capital of the early Kebbi territory was at Leka, but by the time of the celebrated Borno attack in $c$. 1561, the walled city of Surame had been built (Ibid) and thus later remained its 
capital. Deducing from the above perspection, Kebbi remained a critical factor, militarily in Western Sudan as it raids on Air (Azben) resulted in the sought of ruler of Borno for assistance. Though, Air had been a dependency of Songhay since 1501, but in 1532 it had been wrested from the Askias of Songhay by Borno (Letvzion, 1974), this explain the basis of request for Borno aid. It is suffice to construe that, the Borno attack was perhaps only one among many, and was evidently a major attempt to crush the military power of Kebbi. The fame even reached Europe where in $c .1573$, Anania claimed that the ruler of Borno had 'several times put into the field 100,000 men against the King of Kebbi (Trimingham, 1962) and were wantonly subdued. It was a malicious and decisive defeat that, when Kanta Mohammed returned from this expedition that he died as a result of a wound sustained in another combat at Dugul in Kastina territory (Harris, 1966). The foregoing analysis illustrated how military strength was keyed in defense and expansion in Western Sudanic States against the spurious distortion from varied European egocentric scholars.

\section{Songhay Empire Expedition against Kebbi kingdom under the Personal command of Askia Muhammed Bunkan Kirya in c. 1530}

Despite the defeat of Kanta Mohammad, the subsequent leaders of Kebbi did not cease from continue expansion and defence of their territory in maintenance of its feat and the re-assertion of her independence. Indeed, it was able to withstand the military might of its powerful eastern rival, but Kebbi was no less able to stand up to threats from its erstwhile overload to the west. In this situation, in c.1530, a Songhay expedition was launched against Kebbi. Under the personal command of Askia Muhammed Bunkan Kirya, between 1531 and 1537, with surprising candour, the Askia's force were completely routed and thus was the last attempt of Songhay to subdue Kebbi. Though in 1552, a dispute between the new Askia Dawud and Kanta Muhammed was peacefully settled in the following year. However, Kebbi in the subsequent time became resilient from its weakness and challenges as struggle continue to restore its feat.

Paramount to Kebbi military support and defence was evident in the $16^{\text {th }}$ century letter corresponded from the Moroccan, Sultan Al-Mansur to Kanta Dawud in the mid-1590s (Levtzion, 1974). Myriad of allegations were raised and accused Kebbi who have remained a contender and bottleneck to the administrative and political hegemony of Songhay due to its military power. Firstly, the Kanta was accused of giving asylum to the fleeing Songhay leader and aiding them with the cavalry reinforcements. For instance, Al-Mansur's, the Sultan of Morocco demanded that the Kanta should hand over to him the annual gifts of boats and their equipment which he was accustomed to give to the Askia. Since Kebbi was gaining some sort of tributary relationship with Songhay, it did not allowed the belligerent of the Moroccan's ruler to succeed with their aspiration and iniquity. However, it may be true that the annual gift that resulted from the peace negoti- 
ations of I553 formed part of a mutual defence agreement (Ibid).

Secondly, the Sultan of Morocco further accused the Kanta of preventing the people of Kano and Katsina from passing through his territory to make their submission to him-presumably through his Pasha in Timbuktu. In the light of the above, Mai Idris of Borno in 1583 averred that it seems apparent that Sultan Al-Mansur intended to make the whole of Central Sudan, indeed all the lands to the south of Ottoman territory in Africa, tributary to him. In this direction, he however threatened to attack Kebbi if Dawud did not accede to his demand and himself must pay homage to him. In the long run, he was unable to carry out his threat due to his meager forces being over-extended and too preoccupied with pacification of Songhay domains. More also during this time, Kebbi itself was still powerful enough to present a formidable obstacle to carrying out these plans, it did not relent on its oars. It thus continued to avert any cause in the destruction of its eponymous home which they advanced from the convivial relation earlier established.

In the event, the Moroccan forces were only able to effectively hold down the area of the Niger bend from Jenne to Gao and had virtually to abandon the provinces of the south-east. Kebbi on the other hand continue to survive as an independent State in the defunct Songhay for another century or more until internal weakness led to its being divided up among the ruler of Air (Azben), Gobir and Zamfara (Ajayi \& Crowder, 1974). With this, Kebbi did not relent to build on the remaining vestiges, through this; several attempts were made to harness and consolidate it from impending and unseen attacks.

\section{The Factor of Songhay in the Emergence, Consolidation and Recrudescence of Kebbi between the $16^{\text {th }}$ and $17^{\text {th }}$ Centuries}

Economic, social and political factors are the key to the emergence of Songhay empier emergence of Kebbi kingdom, the factors analysis from the preceding part contends that the Kebbi people (Kebbawa) according Trimingham (1962) are a mixture of the two groups who descended from a Katsina mother and a Songhay father. However, the origin and emergence of Kebbi as one of the Kasar Hausa or Hausaland, (Mahdi, 1978) could be best comprehended within the purview of different advantage among which ranged from the navigable nature of Niger River. The astounding fact was the environmental location of Songhay Empire upstream lengthways the arc of Niger River, which was accompanied with so many characteristic geographies. This established the emergence of water transport; fishing expedition; commercial reality; several settlement; and military power. The mixture of these characteristics resulted in the convergence of Songhay administrative power to the centre in Gao, a development critical to the emergence of Kebbi as an independent polity the $16^{\text {th }}$ century. Also, it adequate to note that the centrality of the Songhay type of governance was a matrix that favoured utilization of provincial system through which coordination was ex- 
ecuted by an army.

It is worthy of note that the synthesis of the factors influenced the foundation of Kebbi, by Kanta largely because of his appointment as army commander. Distinct from the aforementioned areas that emanated from Songhay, of paramount among them is the kingdom of Argungu formerly and historically known as Kebbi (Kabi) founded in 1515 by a great veteran warrior, a General Kanta Mohammad popularly identified as Kanta of Kabi. Olagunju (2010) argued that prior to Kanta, Kebbi was one of the twelve provinces under the aegis of Songhay Empire and was a descendant of Uthman Nann Ibn Masud, the leader of Siqaya group, which is the group responsible for water supply in Kaaba at Mecca.

The intricacy leading to the emergence, consolidation and recrudescence of Kebbi could be traced to the last quarter of $15^{\text {th }}$ century as acknowledged by numerous scholars. In the $15^{\text {th }}$ century, Kanta was incorporated into the army of Askias and subsequently rose to the rank of one of the war chiefs and in the meantime, the provincial Governor of Kebbi under the Songhay administration. With the revolt, Kanta ceased from that time to recognise the authority of Askia El-Hajj Mohammmad (Olagunju, 2010) and established himself at Kebbi as an independent State. Through this development in the region, Kanta subdued numerous areas and principalities which were brought under his administrative command and control.

Militarily, Kanta forces were believed to have captured some prominent areas which included Yauri, Nupe and far beyond to the south where their influenced were felt in Oyo and Ibadan. Also in the northwards direction as far as Agades and eastward as far as Zazzau, Katsina, Kano and Daura came under the power of the Kebbi Empire. After the conquests of Zazzagwa, a town near Argungu in-charge of Dankadu (Ibid) was also established. Because of the fame and glory of Kebbi several attack and onslaughts were organised, but were failed due to Kebbi unrelenting struggle and machination militarily.

In detail, Songhay completed two serious attempts to re-assert its embrace over Kebbi. At Wantaramasa in 1530s, Kanta's army inflicted a crushing defeat on Askia Mohammad Benkan. Also, in 1552, Songhay failed woefully in another attack under the personal command of Askia Mohammad, (Olagunju, 2010). This action and development was the final seal on the emergence of Kebbi to a full-scale and blown territory.

As part of the consolidation bid, in the beginning of the $16^{\text {th }}$ century, Kanta Mohammad (or Salih) a local chief of Leka near Gandi built an army and succeeded in overrunning many western Hausa States and rendering them tributary. In his vivacious military sophistication, two years later he assisted the Askiya of Songhay to conquer Air (1514-15). When it came to the division of the spoil, the Askiya demand a third of the tribute of the Hausa State in return for assistance and conflict ensued between the two of them. However, Kanta became infuriated and strategised the siege that eventually defeated the Askiya troops and the latter abandoned the hopes and aspiration nurtured for ruling Hausa land. Again, Air in Hausa parlance mean the Azben or the Azbenawa area remained 
the centre of Tuareg polity whose capacity of Agadez was founded about 1438 . They seem to have paid tribute to both the Askiyas and Kantas with effective control in the hand of the latter. During this period The Kanta was also in control of Gurma and eastern Songhay as far as Tera (Barth, 1858). This scenario is a signification which depicts the military importance of Kebbi in the polity of Songhay as well as Hausaland.

To assuage the administrative control and as well to broker peace in Hausaland, the Kantas Kingdom followed and emulated the usual Sudan lines or the administrative paradigm of allowing the people to rule themselves, the Zarma and Hausa chiefs were left in control of their people with the exception of part of Zamfara, Adar, and Wangara which were absorbed into his personal State and domain. He established his capital at Surame in the native district and built a powerful fortress at Gungu. It is worthy of note that the centre of his power was therefore on the western extremity of Hausaland, (Barth, 1858). With this development, Askiya Muhammed Bengan attacked him and suffered a disastrous defeat. The Kanta was killed about 1545 when returning to his country after winning victories over the force of 'Ali ibn Idris of Bornu. The subsequent Kanta, (c. 1561) was in conflict with Askiya Da'ud in 1552, but concluded a treaty of peace of the following year. The successors of the first Kanta were only able to maintain their power over these States for half a century. Had they been capable, they might have built upon the foundation he laid a power capable of rivaling that of Bornu. In corroboration of the foregoing fact, Muhammed Bello writes: After Kanta, their power endured about a hundred years without weakening until Sarkin Gobir, Muhammed ibn Chiroma, rose against them, together with Agaba ibn Muhammed, Sarkin Ahir (Air) and Sarkin Zamfara. Each of these chiefs took possession of the town which were near to him. But it was Sarkin Zamfara who conquered the greater part and ruined the three principal cities of Gungu, Leka, and Surame (Bello cited in Ajayi \& Crowder, 1974).

This defeat by the Zamfara led to the abandonment of Surame in c.1715 and hence the building of Birnin Kebbi by Tomo as the new capital. The kingdom of Kebbi continued itself as a reduced State, then, owing to its position and the energy of its inhabitants, enjoyed for a time a peaceful life. From several records, it is evident that this expedition was a radical disaster for Askia's army who were virtually, eliminated and subsequently contributed to the collapsed of Songhay Empire. In the last half of the $16^{\text {th }}$ century, Morocco captured three quarters of Songhay Empire, and thus Kebbi and Morocco share a common boundary from 1596 to 1702 (Olagunju, 2010). It will be recalled that from hence forth, the city of Surame built by Kanta in 1515 served as the capital of Kebbi Kingdom up to 1700. The $13^{\text {th }}$ King of Kebbi, King Tomo son of King Ibrahim Tomo who was the son of Kanta decided to abandon the town in 1700 and moved to the south west, where he built Birnin Kebbi as his capital. Against the above backdrop, Birnin Kebbi has since then continued to serve as the capital of Kebbi Kingdom from 1700-1831. In the words of Olagunju (2010), the Kebbawa repulsed the 
Fulbe vigorously and, through they lost most of their territories and were able to maintain their existence in Argungu as a tiny State until the British occupation in 1900 .

\section{Concluding Remark}

The paper has so far examined and interrogated of the factor of Songhay Empire in the emergence of Kebbi in c. 1500s. It is similarly aspect into the military superiority of Songhay and how its disposition led to the consolidation and territorial expansion of Songhay and Kebbi in the period under review. It is good to understand that apart from internal impulse, the Almoravids occupation led by Al-Bakr in 1076 was one of the resultant external factors that culminated in the collapsed of Ghana Empire. This progress took Mali into the attention of political history in Western Sudan and from the second half of the $15^{\text {th }}$ century it became disintegrated and thus eventual emergence of Songhay Empire's rise to glory in the $16^{\text {th }}$ century (Adamu, 1968).

In this connection, Songhay reached its apogee with several settlements along the arc of Niger River upstream in Gao, Walata and Timbuktu towards the Nigeria border in Dendi. Influencing the development in Songhay is the navigability of the Niger River that spurred its centrality to commercial interest and settlements. In addition, Songhay built a formidable military power that defiled all internal and external aggressions, among which composition was a veteran and valiant army General-Kanta Mohammad. His gallantry disposition and unbridle supports to Askiyas of Songhay against all odds of attacks from Air (Azben), Borno, and Morocco among others were very tremendous. By c. 1515, Kanta revolted against the overbearing dominance of Songhay and inequality that emanated from the division of war booty. The resultant effect was the carving of an independent area of influence for himself in Leka as its first capital and later in Surame. During this period, Kebbi subjugated and incorporated many Hausa States of Zaria, Zamfara and Katsina among others to its hold, development which made her susceptible to lot of intrigues. The Kebbi military and political machinations invited series of reprisal attacks which at the end engendered the conquest of Gungu, Leka and Surame. However, Kebbi kingdom because of its military sophistication and unwavering effort, it re-asserted her independence within a shortest period. However, Kebbi attack in the century that followed ultimately subjected her to serious years of debilitation and level of recrudescence that finally resulted in the establishment of its capital in Argungu and later, Birini Kebbi between $c$. 1700 and 1831. Above all, it is therefore pertinent to conclude that navigability of Niger River, centrality of the territory to commercial interests and settlement as well as military might were powerful factors of the Songhay in the emergence of Kebbi in the early $16^{\text {th }}$ century.

\section{Conflicts of Interest}

The author declares no conflicts of interest regarding the publication of this paper. 


\section{References}

Abubakar, \& Mukhtar (2015). History Dissertation, Department of History UDUS (Gungawa and Shangawa Ethnic Groups Who Are Presently Found in Yauri Emirate and Have to a Very Large Extent Traced Their Origins to Songhay People).

Abubakar, Y. (2011). History of the Baresha (Gungawa) People to 1968. M.A. History Dissertation, Sokoto: Department of History, Usmanu Danfodiyo University.

Adamu, M. (1968). A Hausa Government in Decline: Yawuri in the 19th Century. M.A. History Dissertation, Zaria: Department of History, Ahmadu Bello University.

Ajayi, J. F. A., \& Crowder, S. (1974). History of West Africa. London: Longman.

Anene, J. C., \& Brown, G. (1966). African in the Nineteenth and Twentieth Centuries. London: Cambridge University Press.

Barth (1858). History Dissertation, Department of History, Usmanu Danfodiyo University Kanta Was Also in Control of Gurma and Eastern Songhay as Far as Tera.

Fage, J. D. (1969). A History of West Africa. London: Cambridge University Press.

Harris, P. G. (1966). Sokoto Provincial Gazetteer.

Hogben, S. J., \& Kirk-Greene, A. H. M. (1966). The Emirate of Northern Nigeria. London, Harris, P.G. Sokoto Provincial Gazetteer.

Laine, D. (2001). National Geographic. https://www.nationalgeographic.com/

Levtzion (1974). The Hausa Factor in West Africa. London: Oxford University Press.

Mahdi, A. (1978). The Hausa Factor in West Africa. London: Oxford University Press.

Mukhtar, I. (2003). Some Reflections on Hausa Language and Culture among the Yauris. Kano Studies, 1.

Olagunju, A. (2010). International Fishing and Cultural Festival. London: Art Heritage, Ltd.

Trimingham (1957). Notes on the Tribes, Provinces, Emirates and States of Northern Nigeria (2nd ed.).

Trimingham, J. S. (1962). A History of Islam in West Africa. Oxford: Oxford University Press.

Webster, J. N., Boahen, A. A., \& Idowu, H. O. (1967). The Growth of African Civilisation: The Revolutionary Years - West Africa Since 1800. London: Longman Group Ltd.

Yasin, A., \& Mukhtar, T. M. (1967). Songhai Factor in the History of Yauri Emirate, Kebbi State. In J. B. Webster, A. A. Boahen, \& H. O. Idowu (Eds.), The Revolutionary Years: West Africa Since 1800 (Growth of African Civilization). London: Longman Group Ltd. 